\title{
DID RUSSELL EXPERIENCE AN EPIPHANY IN 1911?
}

\author{
ALAN KenNETH SCHWERIN \\ Monmouth University, USA \\ aschweri@monmouth. edu
}

\begin{abstract}
Bertrand Russell's conception of philosophy evolved dramatically in 1911 — the year he fell in love with Lady Ottoline Morrell. For many years Russell had been an ardent advocate of the view that philosophers ought to look for truths that are certain. The co-author of Principia Mathematica altered his commitment to certainty in philosophy in 1911. An analysis of his published views and correspondence from this time strongly suggests that the radical transformation was induced by an epiphany brought about by his emotional entanglement with his lover.
\end{abstract}

Keywords: Knowledge $\bullet$ certainty $\bullet$ epiphany $\bullet$ The Problems of Philosophy $\bullet$ vision $\bullet$ paradigm shift • self • Lady Ottoline Morrell.

RECEIVED: 03/11/2018

ACCEPTED: 25/01/2019

I wanted certainty in the kind of way in which people want religious faith.

Russell, Autobiography

For many, the eyes are the window to the soul. But is there a gateway to the mysteries of the mind? Frustratingly elusive, the mind and its contents can, fortunately for us, be fathomed in a variety of ways. While many strands present themselves, arguably the most secure routes into the mind, especially that of the philosopher, are the rich philosophical fabrics that have been laced together by the thinker - texts both formal and informal. The hidden mysteries of the mind of the philosopher will unfold slowly to patient and persistent enquiries. As my paper will amply illustrate, we have much to gain from an investigation of the correspondence from one of the most prolific philosophers of the twentieth century: Bertrand Russell. While Russell's formal corpus is monumental, his informal correspondence is equally breathtaking, and revelatory.

Changing practically daily, the entries in the annotated catalogue of his correspondence in the Russell Archives at McMaster University listed 131,467 records by early-December 2016. This fascinating resource offers a unique insight into the mind of Russell. More specifically, the correspondence generated by the philosopher from 
Monmouthshire and one of his lovers, Lady Ottoline Morrell, provides us with an invaluable inroad into Russell's philosophical thought precisely when his conception of philosophy and his commitment to certainty experiences a cataclysmic transformation. While Russell's views on philosophy change throughout his life, as has been well documented by numerous critics, my analysis and argument here suggest that 1911 saw an especially dramatic alteration in his conception of philosophy. This seismic shift in his thought is due in large measure to radical alterations in his commitment to certainty: a fundamental transformation - as I shall show — that is induced by an epiphany.

Now Russell is notorious for his numerous melodramatic reports about the changes in his thought and emotional state of mind. Take but one example. Russell's account - dare I say farcical account? - of his decision not to continue living with his wife Alys, allegedly made after a cycling trip in the English countryside, is arguably the most dramatic instance of this hyper attenuated way of characterizing his plight. ${ }^{1}$ As he colorfully puts it in his Autobiography (1872-1914)

I went out bicycling one afternoon, and suddenly, as I was riding along a country road, I realised that I no longer loved Alys. I had had no idea until this moment that my love for her was even lessening. The problems presented by this discovery were very grave... (Russell 1956, p.237)

Really? While this report is arguably a little over the top, it surely does contain a kernel of truth: Russell has made a momentous decision, and he happened to make it while out on his bike. ${ }^{2}$ Okay. So one needs to tread warily when characterizing Russell's situation in the dire terms that I am resorting to. Nevertheless, as I see it, the evidence is incontrovertible that Russell's change of heart on certainty in 1911 is dramatic and noteworthy: a major shift in his philosophical thought that has not received the attention it warrants from scholars. As I see it, the major components of the alteration in Russell's thought on certainty manifest themselves in one of his most famous texts: The Problems of Philosophy. Written over a relatively short span of a little more than seven weeks, this introductory text presents us with a dramatic account of philosophy that appears to vacillate on the role of certainty. While Russell initially embraces certainty in his philosophical investigations here, a strong case can be made - or so I shall argue below - that his views undergo a sea-change within the space of roughly forty-six thousand words. ${ }^{3}$ The initial unqualified commitment to certainty in The Problems of Philosophy is ultimately replaced by an entirely different conception of philosophy that unequivocally embraces uncertainty. Let's consider the textual evidence for these suggestions. To begin with, consider the case for the proposal that Russell, early on in The Problems of Philosophy, is strongly committed to the view that philosophers are striving for certainty in their investigations. 


\section{An unwavering commitment to certainty}

References to certainty feature prominently in The Problems of Philosophy. As a matter of fact, the opening sections of the popular text are replete with allusions to certainty, beginning with the very first sentence:

Is there any knowledge in the world which is so certain that no reasonable man could doubt it? (Russell 1971, p.1, my emphasis)

Russell's modest analysis of some of the issues that concern philosophers opens on a dramatic note that sets the tone for the entire philosophical discussion that follows. But more than mere timbre is presented to the reader early in the book. In many respects, the opening stanza of Problems is even more significant than this as it does more than simply introduce the philosophical issues to his readers in a specific hue. From the outset, Russell draws on his conception of philosophy, with its emphasis on certainty, to guide, if not determine, the focus of the investigation for the bulk ${ }^{4}$ of the fifteen problems that constitute the shilling shocker. ${ }^{5}$

The question that The Problems of Philosophy leads with establishes a framework for the entire work. With Russell immediately drawing attention to the (alleged) role of certainty in our lives and activities, and by implication, to the lives of philosophers, he is laying a foundation for his analysis that is striking: while other issues are important in our lives, apparently it is the concern with certainty that is uppermost in our minds, and by implication, it is the search for certainly that is the single most important issue that motivates philosophers in their endeavors. As he sees it, this is "one of the most difficult" questions we can raise. Had we to consider this challenging question we would be "well launched on the study of philosophy - for philosophy is merely the attempt to answer such ultimate questions..." (Russell 1971, p.1) But the answers that the philosopher proposes will emerge from a critical inquiry only if he ${ }^{6}$ enquires into "all that makes such questions puzzling" - only then will profound, fundamental, rigorous and true answers emerge that are presumably free of the shortcomings that beset the questions and answers from the realm of the nonphilosopher. That is to say, the philosopher's responses to the problematic questions that originate in our society-at-large will ultimately not be besmirched by the "vagueness and confusion that underlie our ordinary ideas". (Russell 1971, p.1) Untainted by the common ideas that are uncritically drawn on and used by the regular members of society, the contributions from the philosopher will be guided by his more philosophical insights and considered ideas - ideas that are robust and unfettered by the obstacles endemic to the thought of daily life. The outcome of this methodical investigation of the questions and ideas from the ordinary world is presumably highly desirable: namely, knowledge of the highest order. As Russell optimistically sees it or at least, as he appears to see it - the philosopher's contribution reputably consti- 
tutes knowledge which is "so certain that no reasonable man could doubt it". (Russell 1971, p.1, my emphasis) ${ }^{7}$

All this suggests that Russell views the philosopher as a skilled laborer, willing and able to assist the reasonable members of society in their quest for a particular brand of knowledge: certain knowledge. And as the knowledge that is sought is not any type of knowledge, but knowledge par excellence - namely, indubitable knowledge - the contributions from the philosopher must be equally impeccable. As Russell sees it, the philosopher fortunately has the requisite tools to help produce this highly desired certain knowledge. The philosopher, as far as he is concerned, is well equipped to carry out this task as he possesses the requisite critical faculties - as well as an invaluable logical apparatus, as he will point out elsewhere - to provide helpful insights into the fundamental questions of society that require attention. ${ }^{8}$ With his philosophical expertise and his refined logical notation, he is able to systematically explore the unexamined philosophical questions from the community that, unfortunately, are encumbered by vague and confused ordinary ideas. The task is to suggest more philosophically rigorous perspectives that are free of the defective ideas endemic to the views current in society-at-large. In the process, the outlook and puzzling questions that the non-philosopher is struggling with ought to dissolve, to be replaced by perspicacious and indubitable insights into the world and its problems.

But is the search for certainty as pervasive as Russell intimates it is? Are nonphilosophers and philosophers alike engaged in a joint enterprise, as Russell appears to assume they are? Are both parties dissatisfied with the knowledge that they currently possess and are they both intent on improving matters? That is to say, are the two sides ultimately striving, for certainty? With the same level of fervor? Russell appears to think so. As he sees it, we are all searching for certainty and starting out from the same starting point:

In the search for certainty, it is natural [for both parties] to begin with our present experiences, and in some sense, no doubt, knowledge is to be derived from them. (Russell 1971, p.1, my emphasis and insert)

This search for certainty is initiated by the realization, on the part of both philosophers and non-philosophers, that the assumptions that underlie our ordinary lives are problematic, requiring substantial effort on our part to produce an outcome that we can rely on - i.e. a set of beliefs that we can regard as certain:

In daily life, we assume as certain many things which, on a closer scrutiny are found to be so full of apparent contradictions that only a great amount of thought enables us to know what it is that we really may believe. (Russell 1971, p.1, my emphasis)

But what reasons are there for adopting this elevated perspective of the outlook of both parties? Why not simply let sleeping dogs lie? More importantly, what evidence 
does Russell present to his reader on these important questions? Take the first question: what reasons are there for assuming that the non-philosopher is actively searching for certainty, as the author of The Problems of Philosophy appears to intimate he is?

While the tendency towards inertia prevails in our non-philosophical lives, Russell clearly assumes that there are individuals in our society-at-large who are dissatisfied with the status quo — individuals who are moved to seek out different ideas that they can regard as certain. But the manner in which he substantiates this assumption of his is interesting. He draws attention to some of the shortcomings of the ordinary ideas from a philosophical perspective. That is to say, the philosopher, by virtue of his more refined philosophical perspective, is able to detect errors that the ordinary citizen overlooks. With his ordinary perspective the naïve non-philosopher is unable to notice the problems endemic to his outlook on "the problems". 9 After isolating a few of our common beliefs on the world around us and its contents - for instance, the view that we are able to perceive physical objects such as windows, buildings, tables, clouds, and the sun - Russell turns to our more fundamental beliefs. Two strike him as especially noteworthy: namely, the belief we have on the veracity of our senses and the belief that we, as ordinary citizens, can accurately describe what we sense:

In daily life, we assume as certain many things which on a closer scrutiny, are found to be so full of apparent contradictions that only a great amount of thought enables us to know what it is that we really may believe. In the search for certainty, it is natural to begin with our present experiences, and in some sense, no doubt, knowledge is to be derived from them. But any statement as to what it is that our immediate experiences make us know is very likely to be wrong. (Russell 1971, p.1, my emphases)

But surely only the philosophers can identify these "apparent contradictions that only a great amount of thought enable us to know what it is that we really may believe". For the philosophers are trained to detect the contradictions - not the nonphilosophers. Why would the latter group of members of society trouble themselves with infelicities in their ideas? Why in the world would they concern themselves with issues that exercise the members of the philosophical community? And if they do explore these philosophical issues, are they not ipso facto becoming more philosophical, if not turning into philosophers?

These are interesting remarks on the role of certainty in our regular, daily lives. Or should I say, the presumed role of certainty in our lives? Russell is clearly assuming that we - the royal "we" is telling here - not only believe in the existence of the physical objects that he confidently refers to, he assumes we are also committed to the view that these beliefs are secure and immune from doubt. It is this additional 
component that strikes me as telling. As he boldly puts it, after his remarks on our beliefs in ordinary objects,

All this seems to be so evident as to be hardly worth stating, except in answer to a man who doubts whether I know anything. Yet all this may be reasonably doubted, and all of it requires much careful discussion before we can be sure that we have stated it in a form that is wholly true. (Russell 1971, pp.1-2, my emphasis)

According to Russell, these inviolable beliefs that we willingly accept and act on in our daily lives are likely to remain unencumbered with invasive (epistemological) questions. But when confronted by an extreme sceptic - i.e. someone "who doubts whether I know anything" - this easy acceptance of the widely held beliefs of daily life becomes a source of much consternation, compelling us to engage in "much careful discussion before we can be sure that we have stated [our beliefs] in a form that is wholly true." (Russell 1971, pp.1-2, my insert)

All this suggests that in the opening section of his The Problems of Philosophy the philosopher is seen by Russell as a benign provocateur, willing to rouse regular citizens from their dogmatic slumbers with fundamental philosophical questions. Initially content with their unexamined ordinary ideas, these unsuspecting citizens soon realize that the philosopher has enticed them from the "high-road from plain common sense" and driven them into a strange and different world of "uncouth paradoxes, difficulties, and inconsistencies": namely, the philosophical world of the sceptic. (Berkeley 2011, p.152). ${ }^{10}$ In short, the world of the ordinary citizen, that has served us well and that has stood the test of time - its vague and confused ideas notwithstanding - is shown to be problematic and in need of refinement, if not replacement. This, unfortunately, is the price that has to be paid if we want certainty, for without the philosophers' perspective we will not "be sure that we have stated [our beliefs] in a form that is wholly true."(Russell 1971, p.2, my emphasis)

This invasive conception of philosophy, with its commitment to certainty, contrasts strongly with Russell's later views of the philosopher and his activities. As we shall see in the following section of my paper, the co-author of Principia Mathematica softens his conception of philosophy towards the end of his shilling shocker, ultimately adopting a more propitious view. For now the philosopher is viewed differently, engaged as he is in a quite different enterprise, encouraging others to add to, or to extend, their initial ordinary perspective. Russell's suggestion that the philosopher broaden his perspective - and presumably assist others to enlarge their perspectives as well - constitutes a major alteration in his understanding of the role of the philosopher in society. In proposing that individuals widen their conceptions of what is possible Russell is encouraging philosophers and regular citizens to be more creative and in the process to actively embrace uncertainty. We need to consider this transformation in Russell's conception of philosophy. 


\section{The virtues of uncertainty and the epiphany}

The journey is demanding and fraught with unexpected turns, but by the time the fifteenth and final chapter of Russell's shilling shocker emerges from the mists of philosophical angst the intrepid reader is likely to find the topic for consideration salutary: the value of philosophy. For surely, with the focus now on the non-technical issue of usefulness or utility - a consideration that the philosophically naïve shop assistant will certainly understand and be able to relate to - the investigation offers the prospect of welcome relief. ${ }^{11}$ With the abstract excursions into idealism, induction, general principles and universals behind him, let alone the intricate investigations into truth and falsehood, with its elaborate analysis of statements on the beliefs of Desdemona and Cassio, the final chapter of The Problems of Philosophy must arrive not a moment too soon for the beleaguered neophyte. But this sense of relief is bound to be short-lived, to be replaced by puzzlement, if not concern, with Russell's concluding remarks on philosophy and its problems. For now the co-author of Principia Mathematica openly courts and promotes uncertainty in philosophy. Not only does Russell encourage the reader to consider uncertainty in philosophy and life in general, he explicitly invites the members of his audience to actively embrace and pursue uncertainty as a desirable end: "The value of philosophy is, in fact, to be sought largely in its very uncertainty". (Russell 1971, p.91) This radical transformation in his thought calls for comment.

As we have seen, when Russell introduces his unsuspecting reader to the travails of philosophical thought he stresses the centrality of certainty, both in society-atlarge and within the academy. According to him, while many problems occupy the minds of the members of both groups, there is one that is especially acute. This is an epistemological question on the status of our knowledge; namely, do we possess knowledge that can be viewed as certain? As he puts it, "Is there any knowledge in the world which is so certain that no reasonable man could doubt it?" (Russell 1971, p.1) With this question as the guiding beacon for the entire enterprise that constitutes The Problems of Philosophy, Russell proceeds to outline a strategy for both parties to pursue. As I have pointed out earlier, Russell suggests that we begin with the evidence provided to us by the senses and look for positions that we can classify as certain: ${ }^{12}$

In the search for certainty, it is natural to begin with our present experiences, and in some sense, no doubt, knowledge is to be derived from them. (Russell 1971, p.1, my emphasis)

So the analyses that follow these opening remarks from Russell presume that certainty is the ultimate objective of the enquiries. We are encouraged to welcome in the considered results of the philosophers' enquiries, as they will be precise, sophisticated answers that emerge from painstaking analysis and reflection on the foibles 
of our ordinary, allegedly defective ideas. ${ }^{13}$ Most importantly, these clean and precise contributions from the philosophers are presumably contributions that we are all entitled to accept and to revel in, for they will be contributions that each one of us can be certain about. Surely the philosophers, who (apparently) are focused on important, fundamental questions, as the opening section of the text suggests is the case, are providing us with their elaborate philosophical contributions not because they view their work as inconsequential and of little value to society-at-large, but because they assume that the outcome of their efforts are of value? And it is the certainty of their results - a highly prized attribute of their contributions, in Russell's eyes - that presumably ensures that their efforts are worthwhile. Why then is Russell suddenly talking about uncertainty? Is this an implicit admission on his part that the philosophical problems that he has explored in the project — and for that matter, any other philosophical problems that he could have included in his journey - are difficult, and likely to yield counterintuitive results that shop assistants will not find valuable? More pointedly, is Russell's emphasis here on uncertainty - an emphasis that only emerges at the very end of his investigation into some of the leading problems of philosophy - an admission of failure on his part? Is his decision here to embrace and celebrate uncertainty in his philosophical investigations a tacit admission that the search for philosophical views that even shop assistants will regard as certain, is ultimately futile?

Perhaps. This uncompromising, deflationary interpretation of Russell's remarks on uncertainty appears to have some textual support. For Russell is the first to admit that the output from philosophers - and this must include him — is not held in high regard by society in general:

$[M]$ any men, under the influence of science or of practical affairs, are inclined to doubt whether philosophy is anything better than innocent but useless trifling, hair-splitting distinctions, and controversies on matters concerning which knowledge is impossible. (Russell 1971, p.89, my emphasis)

When all is said and done, the philosopher appears to have little to offer society. ${ }^{14}$ Apparently, nothing that they say can even be regarded as knowledge. And in that case, it follows that whatever emerges from the philosophers' deliberations cannot be certain. From both a scientific and practical perspective it seems then that their contributions, at best, can be classified as uncertain suggestions. Are we to conclude from all this that the results of the philosophers' investigations into the problems of daily life are ultimately to be classified as little more than useless perambulations?

For Russell, this defeatist conclusion is misplaced. We do not need to go this far in our assessment of the results of the investigations conducted by the philosopher. While the philosopher needs to concede that his contributions are modest, the contributions, nevertheless, are valuable in that they assist in the enlargement of the 
not-Self. As he sees it,

... true philosophic contemplation... finds its satisfaction in every enlargement of the not-Self, in everything that magnifies the objects contemplated, and thereby the subject contemplating. ... The mind, which has become accustomed to the freedom and impartiality of philosophic contemplation will preserve something of the same freedom and impartiality in the world of action and emotion. It will view its purposes and desires as parts of the whole... Thus contemplation enlarges not only the objects of our thoughts, but also the objects of our actions and affections: it makes us citizens of the universe... (Russell 1971, p.93, my emphases)

Russell has clearly undergone a paradigm shift in his conception of philosophy. There can be little doubt that the co-author of Principia Mathematica has acquired a new and profoundly different understanding of the outcome of philosophical investigations. And his newly acquired insight into the results of these fundamental investigations influences his views on the initial impetus for these enquiries. For it turns out that the questions that motivated the philosopher to explore the (allegedly vague and confused) ideas of ordinary citizens are unable to yield results that are certain. While both the philosopher and his non-philosophical companion are presumed to be looking for certainty, there, unfortunately, will always be unresolved issues that call for further investigation. In his letter to Morrell on 13 December 1911 Russell puts this succinctly:

All the historic problems of philosophy seem to me either insoluble or soluble by methods which are not philosophical, but mathematical or scientific. The last word of philosophy on all of them seems to me to be that a priori any of the alternatives is possible... [P] hilosophy, it seems to me, can only say that all the arguments adduced on either side are fallacious, and that there is absolutely no evidence either way.

So the quest for definitive answers to our philosophical questions will not yield results that are sacrosanct: an outcome, as Russell sees it, that strongly suggests that the search for certainty in philosophy is futile. Is this to suggest that the exploration of the world of the philosopher is equally pointless? Not at all, intimates Russell.

The challenging journey into the philosophers' world is far from unproductive, as it ultimately engenders a radical transformation in the minds of the explorers. Initially desiring certainty, we ultimately find that our conceptions of what is possible are broadened by our philosophical endeavors, thus drawing us closer to our universe, and the people who populate it. How do we account for this dramatic transformation in Russell's views on the impact of philosophical enquiry? In a word, it appears that the conversion in his thought amounts to an epiphany. Let me elaborate.

My suggestion is that Russell has experienced an epiphany, or a quantum change in his conception of philosophy. The evidence strongly suggests that he has undergone 
a radical alteration in his philosophical thought that has been induced by his intimate association with the spiritually inclined Lady Ottoline Morrell. Epiphanies, as Miller and C' de Baca point out are

... quantum changes [that] are experienced as personal transformations whose hall marks are vividness, surprise, benevolence, and a conviction that the change is permanent. (Miller and C' de Baca 2001)

Many prominent intellectuals are thought to have experienced epiphanies in their lives. Perhaps the most famous epiphanies that have been documented and systematically studied are the radical transformations experienced by Dostoevsky and Tolstoy. The evidence suggests that both of these intense Russian writers experienced dramatic changes in their psyche, undergoing radical psychological transformations that amount to quantum changes in their respective outlooks on life. Their moving memoirs testify to these alterations. ${ }^{15}$ In his correspondence to Lady Ottoline in 1911, Russell makes it clear that his outlook on philosophy, and on life in general, has similarly altered in a radical manner. As he sees it, his capacity for genuine empathy for others, his ability to see the world more clearly and his feelings for others have all been substantially increased. With his newly acquired heightened powers Russell is encouraged to adopt a dramatically new perspective on the role of philosophy in our lives. And as Russell sees it, these alterations are largely, if not exclusively due to Lady Ottoline Morrell's influence on him.

In their voluminous correspondence references to the impact of Morrell's views on Russell's conception of philosophy are ubiquitous. Letters written by Russell during the first year of their intense relationship - a relationship that would last twentyeight years - contain numerous references to her influence on his thinking. More specifically, the correspondence between Morrell and Russell often alludes to the transforming influence of Morrell on her lover from the department of philosophy from Cambridge University. What is especially significant is the fact that Russell explicitly acknowledges her influence as The Problems of Philosophy reaches its conclusion. That is to say, as the fifteenth, and final chapter on the virtue of uncertainty is being written and proofed, Russell makes it clear to Morrell that she has played a major role in the radical alteration in his thinking on fundamental matters. Here are but four of the most poignant passages from the substantial, emotionally charged correspondence produced by Russell during this period that makes reference to her influence:

- You don't know what a difficult thing it is for me to feel peace, yet with you I feel it completely. Generally I have such a reaching out after the infinite such a blending of my own discontent with all the sorrows of the world and all the wretchedness of human life, that I feel existence itself inherently a curse, 
and unconsciousness the only real blessing... I never found a happiness before that filled me - pain filled me, but happiness always seemed to omit what was really most serious. Now that is all different and when I am with you no inmost recess remains unsatisfied - it is because of some quality of infinity in your love - making your love [?] like God's. That is what raises it so far above what I could have imagined. (Letter from Upper Wyche, July 10, 1911)

- It is not chiefly from vanity that I want to think well of the work I have been doing lately. It is chiefly because I want it to be a worthy outcome of our love, and a proof to you of the help you give me. It really is the truth, and not delusion, that my powers have expanded lately. I have more freedom, more mastery, more insight, more energy. If you had been the most eminent philosopher of the age, I could not have given you more of my mind than I have given. This last month, I have given you everything I have thought, and all my best thinking has been when I was with you. (Letter from Ipsden, August 11, 1911)

- My darling, it is incredible how you have changed my life - it is all so much easier - before, I was always struggling and always falling short, and so filled with inward discords. Now it is utterly different. I feel I have so much to give to everyone - and I don't have any longer the restless longing to give that made me give too much and to the wrong people. (Letter from Trinity, Wednesday October 18, 1911)

- I cannot tell you how amazingly you increase the fruitfulness of my thoughts; you help them to come to the surface and to clothe themselves in beauty, and you make me know what is dross and what is gold. This is so wonderful in our love, that with such immense happiness there is always the sense of pressing forward into new and fuller and wider vision. (Letter from the train, 22 January 1912)

So Russell suggests that he has acquired a new vision, has more energy, that his (intellectual) powers have expanded lately and that he is now producing some of his best philosophy with Morrell. With the shilling shocker behind him, with its initial emphasis on certainty in philosophy, Russell proudly proclaims that he has changed. This dramatic transformation that has been inaugurated by Morrell has ushered in a new Russell, with his newly found emphasis on creative uncertainty: a dramatic alteration that comes as a surprise to the aristocratic, self-centered and hard professor of philosophy. As he puts it, "it is incredible how you have changed my life - it is all so much easier - before, I was always struggling and always falling short, and so filled with inward discords. Now it is utterly different. I feel I have so much to give to everyone." (Letter from the train, 22 January 1912)

Morrell is clearly moved by Russell's remarks about her influence on his newly acquired views on philosophy. As the manuscript is making its way to the press, Mor- 
rell sends Russell a letter from Peppard Cottage, Henley-on-Thames that shows her delight in his transformed conception of philosophy:

I wish you knew all the great happiness you give me when you say that you know your powers have expanded. It is difficult for me to tell but I should quite believe that they have and that you have broken through some wall and have come out into a world of light and of possibilities and of visions that you were not in before although you often saw into it, and had all the love of it in you and desire for it. (Letter from Peppard Cottage, August 12, 1911; my emphases)

From the correspondence between Russell and Morrell we learn that Russell makes frequent references to the impact that his lover is having on his thoughts. As the shilling shocker takes shape, and especially after its completion, with its famous fifteenth chapter on uncertainty in the investigations conducted by philosophers, Russell informs Morrell about the sudden transformation and draws attention to her role in the changes in his conception of philosophy. His lover humbly acknowledges his overtures, and encourages him with the suggestion that his new philosophy will be well received. The reception of the transformed ideas from Russell, as Morrell sees it, will be superior to that accorded Spinoza, even with his "great vision":

Yes, your ... new work will be ... less elusive and more applied to our present life [than that from Spinoza]. I believe it will have a very great effect on many people ... [and] will lift them out into life and freedom and love and union with others and service. (Letter from Peppard Cottage, August 12, 1911)

With accolades like this it is no wonder that Morrell makes it clear that she looks forward to working through The Problems of Philosophy, especially the famous final chapter that celebrates uncertainty in philosophy: "I am impatient to hear your chapter. I hope you were able to write it all right yesterday." (Letter from Peppard Cottage, August 12, 1911)

While Morrell admits that she is not in the best position to judge whether or not Russell has actually broken through into a new vivid set of visions, she is clearly excited by the prospects, and keen to read first-hand about Russell's new conception of philosophy. Having spent the previous six months listening to and conversing with her philosophical mentor, with his unwavering commitment to certainty in philosophy, the thought that she will now be afforded the opportunity to explore a wide range of diverse, and more accessible ideas, from her newly energized philosopher who is extoling the virtues of uncertainty, proves intoxicating. The epiphany that Russell has experienced while completing his lonely excursion into the problems of philosophy for Gilbert Murray has not only liberated the co-author of Principia Mathematica, it has helped cement the evolving intense relationship between Russell and Lady Morrell. 


\section{A final thought or two}

In the postscript to his Autobiography (1944-1969) Russell points out to his readers that he did move away from his long-held commitment to certainty relatively early on in his career. After explaining that initially he "wanted, on the one hand, to find out whether anything could be known; and, on the other hand, to do whatever might be possible toward creating a happier world", Russell draws attention to the role certainty played in the "serious part of his life". ${ }^{16}$ (Russell 1969, p.326) While the quest for knowledge that is certain and the desire to create "a happier world", apparently motivated him in his youth, Russell suggests that it was his interest in and concern with the human condition that drove him from his preoccupation with certainty:

Up to the age of thirty-eight I gave most of my energies to the first of these tasks. I was troubled by scepticism and unwillingly forced to the conclusion that most of what passes for knowledge is open to reasonable doubt. I wanted certainty in the kind of way in which people want religious faith. I thought that certainty is more likely to be found in mathematics than elsewhere... Then came the First World War, and my thoughts became concentrated on human misery and folly. (Russell 1969, pp.326-7, my emphasis)

As late as one year before his death Russell suggests that it was the First World War, with all its "human misery and folly", that drove him to adopt a conception of philosophy that celebrated uncertainty. This account of his dramatic transformation on the role of certainty in philosophy, however, does not appear to be consistent with the evidence. As I have attempted to show in my paper, an investigation of his evolving views on philosophy in The Problems of Philosophy, along with an exploration of the correspondence between Russell and Lady Ottoline Morrell around 1911, strongly suggests that Russell experienced a paradigm shift on philosophy long before the war broke out. While the Great War might have intensified Russell's growing interest in the plight of humanity, as I see it, it was not his concerns with "human misery and folly" that drove him to relinquish his commitment to certainty. There can be little doubt that Russell experienced an epiphany a full three years before the outbreak of the First World War; namely, while putting the finishing touches to his shilling shocker. As my argument and analysis of the correspondence between Morrell and the aristocratic Cambridge philosopher suggests, Russell's 1911 work on his introduction to the problems of philosophy ultimately broadened his conception of philosophy and invited in uncertainty. Whether or not the exchanges with his lover, Lady Ottoline Morrell, actually played any role in the inauguration of the quantum changes experienced by Russell — Russell's own assessment not withstanding - is another matter, calling for attention elsewhere. ${ }^{17}$ 


\section{References}

Bidney, M. 2004. Epiphany in Autobiography: The Quantum Changes in Dostoevsky and Tolstoy. Journal of Clinical Psychology 60(5), 471-80.

Miller; C' de Baca. 2001. Quantum Change: When Epiphanies and Sudden Insights Transform Ordinary Lives. Guilford Press.

Monk, R. 1996. Bertrand Russell: The Spirit of Solitude. Free Press.

Russell, B. 1971. The Problems of Philosophy. London: Oxford University Press.

1951. Autobiography. Boston: Unwin Paperbacks.

1956. The Autobiography of Bertrand Russell (1872 - 1914). Boston: Little Brown.

1969. The Autobiography of Bertrand Russell (1944 - 1969). New York: Simon and Schuster.

Schwerin, A. 1999. A Lady, Her Philosopher and a Contradiction. Russell: 5-28. . 2011. Reason and Belief: Great Issues in Philosophy. New York: Whittier. . 2017. Is Russell's conclusion about the table coherent? In: Stone 2017, pp.107-35.

Stone, P. (ed.) 2017. Bertrand Russell's Life and Legacy Delaware: Vernon Press.

\section{Notes}

${ }^{1}$ A second, equally dramatic report is the account of his emotional state of mind and the changes in his thinking on learning of the illness of Evelyn Whitehead, the wife of Russell's colleague, Alfred North Whitehead. This emotional transformation apparently induced a major alteration in Russell's views about the Boer War; initially a staunch supporter of the British Imperialists in their escapades in the South African veld, Russell saw the world alright after a sobering encounter with the ailing Mrs. Whitehead. Within minutes, apparently, he dramatically switched allegiances to the pro-Boer movement:

When we came home we found Mrs. Whitehead undergoing an usually severe bout of pain ... Suddenly the ground seemed to give way beneath me, and I found myself in quite another region... At the end of those five minutes, I had become a completely different person. For a time, a sort of mystic illumination possessed me... Having been an imperialist, I became during those five minutes a pro-Boer and a pacifist. (Russell 149, 1951, my emphasis.)

${ }^{2}$ A leading critic of Russell argues that "though Russell clearly massively exaggerates as was his wont - the extent to which it was a sudden and unexpected revelation, there seems no reason to doubt that there was a bicycle ride and that there was a moment when he ceased to struggle against the facts and to admit to himself that he no longer loved Alys." (Monk 1996, p.145)

${ }^{3}$ I have not counted the words in his text. However, in his August 7, 1911 letter to Murray, Russell says that he is sending "the greater part of my treatise for your shop-assistants, the rest will follow quickly ... I think the total is about 46,000 words..."

${ }^{4}$ While most of the text is dominated by Russell's predilection for certainty, the final chapter - that is strongly influenced by Lady Ottoline's spirituality — is a striking aberration in that it celebrates uncertainty, as I intend to show below. 
${ }^{5}$ When did Russell first refer to The Problems of Philosophy as a shilling shocker? I can't be sure about this. He uses the term - actually an abbreviated version of the term - at an early stage in the project, in a letter to Lady Ottoline, when referring to Moore's contribution to Murray's series:

Moore and I compared notes on our respective S.S's yesterday. He is making his just as difficult as his Principia Ethica - He has only one style and method, and can't alter for a different audience. He seems to be rather more behindhand with it than I am with mine. (Letter to Morrell 8 July, 1911, my emphasis.)

Russell's use of the abbreviation "S.S" must surely be shorthand for "shilling shocker". As far as I can determine, he does not use this term where we would most expect him to do so namely, when corresponding with his editor, Gilbert Murray.

${ }^{6}$ For convenience, I am using the words "he" and "his" to signify both male and female philosophers. The alternative strikes me as cumbersome.

${ }^{7}$ This qualification is important, as Russell never comes out and explicitly answers his opening question on the standing of the philosophers' response to the question. I am assuming that this is Russell's assessment of the contributions from the philosopher who answers the call for "knowledge... which is so certain that no reasonable man could doubt it?" That is to say, the philosopher ought to be praised for his contributions - they are free of the defects that beset society-at-large and are to be welcomed for their surety.

${ }^{8} \mathrm{I}$ am alluded here to the formal notation from Principia Mathematica - a symbolism designed by Whitehead and Russell, in large part, to assist philosophers in their attempts to clarify and more fundamentally grasp the issues endemic to the puzzles that bedevil ordinary citizens.

${ }^{9}$ As Russell sees it, there are unnoticed problems lurking below the surface - but they manifest themselves only when the philosophical perspective is adopted. For this reason, some might suggest that for the non-philosopher, there actually is no problem to start with. The difficulties emerge only after the adoption of the philosophers' perspective. In short, claims about the existence of problems are relative to the outlook of the individuals involved.

${ }^{10}$ I am alluding to George Berkeley's assessment of the impact of the philosopher on the unsuspecting ordinary citizen. In his Treatise Concerning the Principles of Human Understanding Berkeley bemoans the sinister outcomes of the questions philosophers direct at the contented members of society-at-large.

${ }^{11}$ It is important to remind ourselves that the project that originated in suggestions from Gilbert Murray started out with noble intentions: to introduce philosophy to a non-academic audience. Murray asked his colleague to write an introduction to philosophy that even relatively uneducated workers could understand. On September 191910 Murray writes to Russell with an invocation to contribute to his series:

You have got a message to the shop-assistants about philosophy, if you would only think it out. If you don't want to tell them what Mathematics is, can you not tell them what Philosophy is? You could do it with great detachment from the conventional schools, and you could put all the main problems in their very lowest terms. (My emphasis) 
This suggestion from Murray that Russell can put "all the main problems in their very lowest terms" has been critically explored in my recent paper, "Is Russell's conclusion about the table coherent?" in Bertrand Russell's Life and Legacy, edited by Peter Stone.

${ }^{12}$ Others have also gone down this path. René Descartes, for instance, in his search for certainty in Meditations on First Philosophy also opens his philosophical enquiry with the suggestion that we consider the contributions from the senses:

What I have so far accepted as true par excellence, I have got either from the senses or by means of the senses. (From Reason and Belief, edited by Alan Schwerin, p.139)

As with Russell, Descartes' quest for certainty initially disappoints him. For Descartes, philosophy initially drives one towards malignant skepticism, with its forebodings on the senses and the possibility of an evil deceiver. And as with Russell, Descartes soon turns to his religious views to extricate him from his philosophically induced morass. While Descartes ultimately finds solace in his enquiry into his idea of God, Russell suggests that philosophical reflection can free the mind from the restrictive bonds of instinct: "The free intellect will see as God might see, without a here and now, without hope and fears without the trammels of customary beliefs and traditional prejudices... " (Russell 1971, p.93)

${ }^{13}$ If Russell, in the final chapter of his introduction to philosophy, is inviting uncertainty into the lives of his readers, both philosophical and non-philosophical, a pressing issue arises: What precisely do we do with the old, discredited views? To the best of my knowledge, Russell does not address this question in his primer into philosophy.

${ }^{14}$ Russell will later bemoan the low estimation accorded his magnum opus, Principia Mathematica. Writing from Plas Penrhyn on June 9, 1963 to a Ms Hilton, thanking her for the complimentary copy of her recently completed book on logic, Russell thanks her for the compliments on his logic book:

I am grateful for the nice things you say about Principia Mathematica and about me. The followers of Gödel had almost persuaded me that the twenty man-years spent on the Principia had been wasted and that the book had better been forgotten. It is a comfort to find that you do not take this view. (Russell 1975, p.672)

In his view, not only was the work not appreciated, Principia did not have the audience it deserved. After all his efforts, along with those of his colleague Whitehead, Russell says this about the (sparse) reception accorded the book:

I used to know of only six people who had read the later parts of the book. Three of these were Poles... the other three were Texans... (Russell 1956, p.86)

While these are surely exaggerations, one wonders if there are elements of truth to Russell's remarks here.

${ }^{15}$ In his "Epiphany in Autobiography: The Quantum Changes in Dostoevsky and Tolstoy" Martin Bidney spells out in detail the stages in the psychological transformation that the two great Russian writers experienced (Bidney 2004).

${ }^{16}$ What precisely does Russell mean with this phrase, "the serious part of my life"? He does not tell us. Given the role of certainty early on in his philosophical thought, it is highly probable, in my view, that Russell is at least alluding here to his academic activities at Cambridge 
and to the technical work he did immediately afterwards on "serious" matters i.e. work on problems that the academic philosophers would find interesting and worthy of comment and analysis, and that during this phase in his life Russell was taken with the search for certainty.

${ }^{17}$ An investigation of the correspondence between Morrell and Russell leads us to suspect that her spirituality provided a powerful stimulus for Russell's adoption of a more rounded, humane conception of philosophy. There can be little doubt that Russell's ultimate commitment to uncertainty in philosophy was influenced by his evolving views on the self - changes brought about by his emotional entanglement with Lady Ottoline Morrell in 1911. On this important factor in the development of Russell's thought, see my paper, Schwerin (1999). 